\title{
A Case of Nevus Cell Nevus Occupying the External Auditory Canal
}

\author{
Takashi Nasu ${ }^{122)}$, Toshinori Kubota ${ }^{1)}$ and Naoto Yoshizaki ${ }^{13)}$
}

\begin{abstract}
We report herein on a patient with a bulky nevus cell nevus in the external auditory canal. A 43-yearold woman had a feeling of fullness in the right ear and noticed a tumor in the right external auditory canal. When the patient was first seen, a pedunculated mass lesion located at the base of the entrance to her right external auditory canal was found. As its appearance was skin-colored, it was difficult for us to make a diagnosis of nevus cell nevus at first view. It was diagnosed as a dermal nevus by a dermatologist at our hospital. We decided on the course of treatment after receiving advice from a dermatologist, and removed it surgically. Dermal nevi should be resected because of their potential for malignant change for cases and locations in which careful observation is difficult, such as in the external auditory canal.
\end{abstract}

Keywords : nevus cell nevus, dermal nevus, malignant change, tumor of external auditory canal

\section{References}

1）川村太郎：色素性母斑およびその類症. 日本皮膚科全書 第 7 卷（北村包彦編）。72-73 頁，金原出版，東京， 1957 .

2）清水友収, 生駒尚秋, 横山道明: 外耳道黒色腫の一例. 耳 鼻咽喉 49: 417-419, 1977.

3）小林英人, 大野吉昭, 渡辺行雄, 他 : 外耳道色素性母斑の 一症例. 耳鼻展望 24：613-616, 1981.

4）杉浦 茂: 外耳道黑色腫の 1 例一外耳道良性腫瘍症例の検 討一。耳鼻咽喉 43: 527-531, 1971.

5）内田利男, 高川直樹：外耳道良性腫瘍 3 症例一263症例の 検討一。耳喉頭頸 60：753-756, 1988 .

6）森本賢治，久々湊靖，志藤文明，他：外耳道色素性母斑の 10 症例. 耳鼻と臨 35: 1028-1032, 1989.

7) Arnold HL : Melanocytic nevi and neoplasms. Andrews'diseases of the skin: clinical dermatology (ed by Anthony N). pp 808830, WB. Saunders Company, Philadelphia, 1990.

8) Monnier Y, Pasche P, Monnier P, et al. : Second primary squamous cell carcinoma arising in cutaneous flap reconstructions of two head and neck cancer patients. Eur Arch Otorhinolaryngol 265: 831-835, 2008.

9) Domonkos AN : Melanocytic Nevi and Neoplasm. Andrews' diseases of the skin: clinical dermatology (ed by Anthony N). pp 870-875, WB. Saunders Company, Philadelphia, 1990.

10) Lim HJ, Kim YT, Choo OS, et al. : Clinical and histological characteristics of melanocytic nevus in external auditory canals and auricles. Eur Arch Otorhinolaryngol 270: 3035-3042, 2013.

11) Herschorn A : Dermoscopy for melanoma detection in family practice. Can Fam Physician 58: 740-745, 2012.

12) Wanebo HJ, Cooper PH, Young DV, et al. : Prognostic factors in head and neck melanoma. Effect of lesion location. Cancer 62: 831-837, 1988.

13) Kazikdas KC, Onal K, Kuehnel TS, et al. : An intradermal nevus of the external auditory meatus. Eur Arch Otorhinolaryngol 263: 253-255, 2006.
1) Department of Otolaryngology, Yamagata City Hospital SAISEIKAN

2) Department of Otolaryngology - Head and Neck Surgery, Yamagata University Faculty of Medicine

3) Department of Otolaryngology, Sendai Shakai Hoken Hospital
Corresponding Author Address : Takashi Nasu tanasu@med.id.yamagata-u.ac.jp 


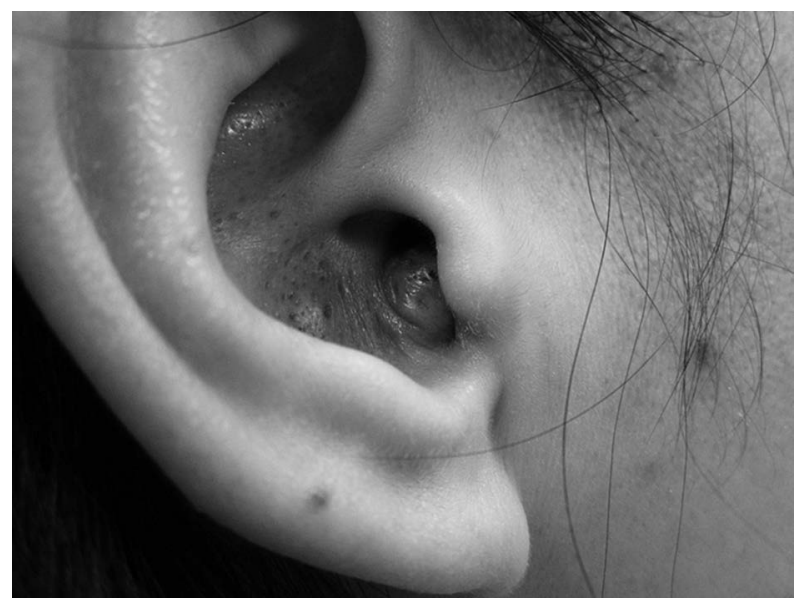

Finding of the right external auditory canal at the first visit A tumor is seen occupying the right external auditory canal.

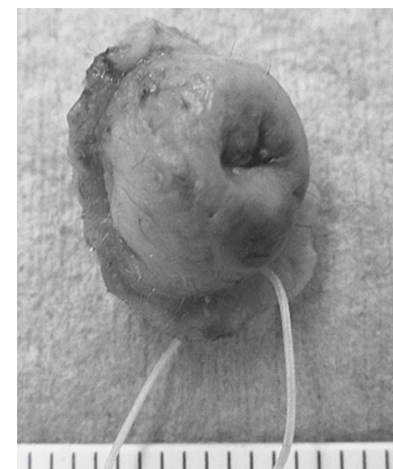

A

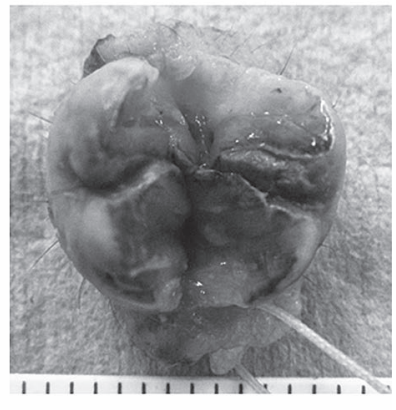

B
The tumor removed from the right external auditory canal A: A complete view of the tumor, B: The cut surface of the tumor



A

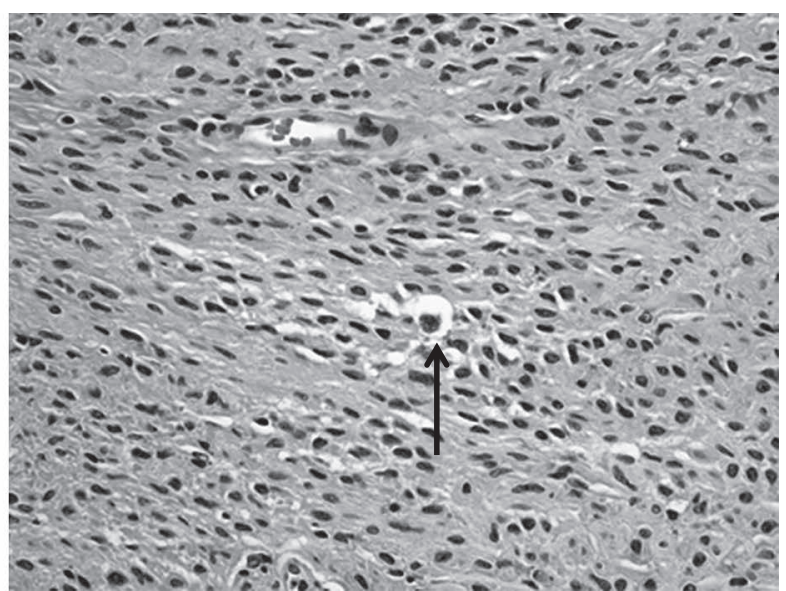

B

Histopathological findings

A: HE-staining, $\times 4$ B: HE-staining, $\times 40$

$\boldsymbol{\Delta}$ : Nevus cell nevus including subdermal melanin pigment

$\uparrow:$ nevus cell including melanin with neurodifferentiation 